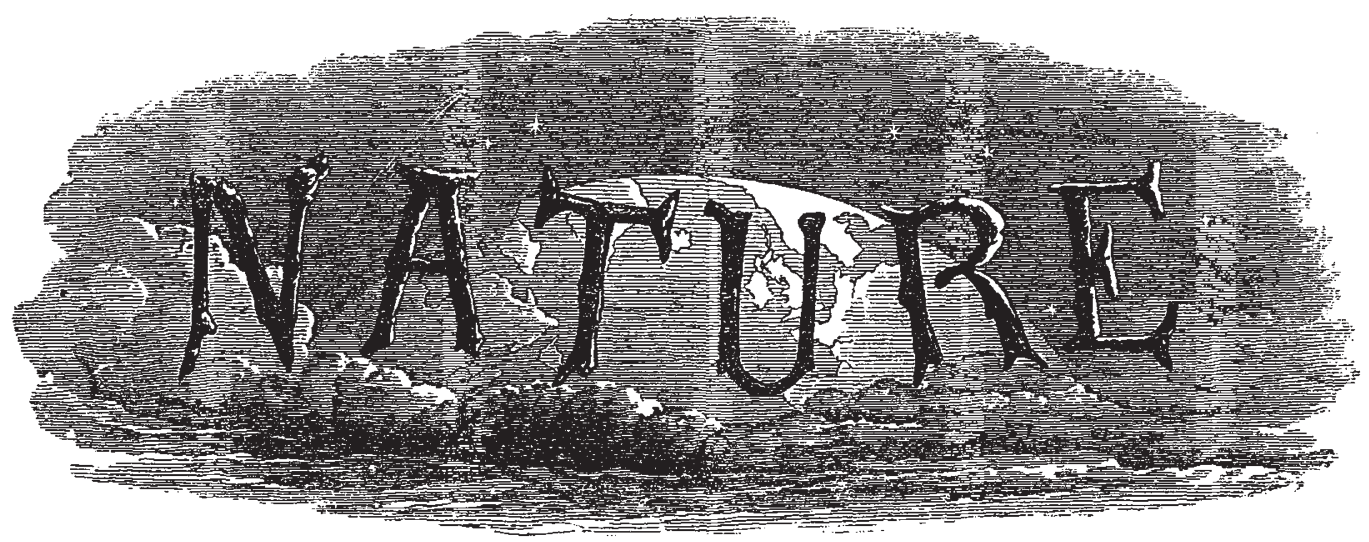

A WEEKLY ILLUSTRATED JOURNAL OF SCIENCE

" To the solid ground

Of Nature trusts the mind which builds for aye."-WORDSWORTH

THURSDAY, MAY 2, 1872

\section{THE CIVIL ENGINEERS' BANQUET}

$W^{\mathrm{E}}$ do not grudge our friends the Civil Engineers their annual felicitations, nor Mr. Gladstone his congenial moral reflections. It were hardly worth while to dissect after-dinner rhetoric, however full of fallacies. But those ever-watchful teachers of mankind, the daily press, have pounced upon the speeches delivered on Wednesday week, and have made them an occasion for propounding solemnly what was spoken hilariously; and this deserves looking to.

The Times, of course, armed at every point, does battle valiantly for decentralisation of science, because that notion seemed to find favour with the notabilities of the evening. Mr. Hawksley, president of the Civil Engineers' Institute, in toasting Her Majesty's Ministers, complimented them on the "performance of the negative duty of letting his profession alone," adding, with unconscious satire, that what the engineers had done "they had achieved, not through, but in spite of, all Governments." These two sentiments are quite intelligible and quite true; but the conclusion of the speech, which informs us that "the Civil Engineers of this country approached the Government with perfect reliance on its purity," conveyed a needless truism; to the pure all things are pure-to pure engineers even a British Government is pure, of course. But why dwell on so obvious a fact ?

Well, this put Mr. Gladstone on his mettle. At once absorbing the tribute to their inaction-rather a novel compliment to his Administration - he evolved out of it this syllogism : Engineering is science; engineering likes being left to its own devices; therefore all science should be left alone. This sort of logic is quite good enough for dinner talk, but not for breakfast reading. What may be excused to convivial excitement in a flattered guest cannot always be permitted to a journalist after an interval for reflection.

The Times of the 26 th ult., after expatiating on the advantages of non-intervention in things in general, thus disposes of science. "If," it says, " under such conditions of Government, the State does nothing for science, it cannot be helped; nor need it be much lamented, con- sidering how very little science stands in need of the aid. If," it goes on to say, "the Institution of Civil Engineers had been a creation of the State, fostered by State bounties, and favoured by State protection, its members would never have acquired such a position in the ccuntry as they justly boast of holding now. As it is, they have fought their way and been the founders of their own fortune ; and so their president has the pleasure of telling the Prime Minister of the Kingdom that he and his constituents have been and are independent of all Governments whatever."

We give the sentence entire, because the nonsense it contains does not admit of greater condensation. Let us examine it a little. How is the engineering profession typical, as here asserted, of science? What is that profession? Simply, and without any intended offence, a profession for making money. Men put their sons into it, and have them trained, rather imperfectly in England it must be confessed, and push them forward in it, solely because the contracts, commissions, and fees, are enormous, and the chances of making a fortune pretty fair. We by no means object to this in a broad way. Other professions, held in high honour-the law, for instance-are exactly in the same category. If men possessed, or believed to be possessed, of special knowledge, find that a high price is put on that knowledge in the market, they are of course justified, as long as they perform honestly what they undertake, in demanding the highest price they can get for it. But in this respect how do they differ, not merely from lawyers, but from manufacturers and even from tradesmen? Is there any difference between making and selling so many yards of calico and so many miles of railway, between supplying customers with patent umbrellas and a patent locomotive? All are results of science, and may be products of brains other than those of the vendors. If engineers are able, by vending bridges, railways, and graving docks, to amass in a few years colossal fortunes, as we know they do, what Government help can they need more than the successful cotton lord, or the enterprising grocer, who also manage their business without external aid?

This being granted, why, asks the Times, should not the principle of non-intervention be applied to science? Simply because what is generally understood by the term "Science" is not a remunerative occupation. We do 
not say that no one ever made money by pure science; some men have done so, as is well known, by means such as telegraphic inveritions and chemical processes applied to the arts ; but even these, and they are very few, have not become the millionaires, of whom not a small number are to be found amongst engineers and manufacturers. Putting aside these rare exceptions, science does not bring wealth to its cultivators. For instance, who ever made money by astronomy? What did the discovery of Neptune, the highest scientific achievement of this age, bring to Professor Adams but tardy fame? Are investigations of the properties of light, sound, gravity, magnetism, profitable pursuits? Was the inventor of a new calculus ever made rich thereby ?

Shall we contend, therefore, that Government should supply the shortcomings of a scientific career, and place those who adopt it on a par pecuniarily with successful engineers? By no means. We must look a little deeper for the reason why State should aid Science. We shall find, if we examine the whole domain of Science, that there are extensive tracts which require for their vigorous cultivation very costly appliances and a long expenditure of time. Poor men cannot afford the one at all, and cannot live if they devote themselves to the other without remuneration. Hence, if such branches of science do not receiveaid from without, they must languish, if not be entirely neglected. But this cannot happen without depriving the community of some addition to its material advantages which it might otherwise possess. It is notorious, not, perhaps, to all the writers of the Times, but to those conversant with the state of science in England, that this evil is with us in full operation with constantly increasing force. Rich men do, it is true, sometimes devote themselves to science. But no individual can do more than labour during his lifetime; and what is chiefly wanted now, in several of the most important lines of investigations, is uninterrupted continuity during immense periods of time. Will our friends, the Engineers, apply some of that "lavish liberality and unbounded enterprise," of which we have heard so much, in this direction? We suppose not. Whatever may have been the love of know ledge for its own sake which distinguished the first founders of the profession, the modern "leading engineer" knows better than to put his money and time into so unprofitable a business.

England is at this moment behind every other civilised nation in the means afforded for the cultivation of those branches of science which do not yield immediate profit. But there are men, not connected with either the Government, the Times, or the Civil Engineer Institute, who are alive to the peril of prolonging this neglect, and who will not rest until they have opened the eyes of their countrymen to its imminence and magnitude, at present beyond the ken of their governors and their teachers. When they have attained their object, the Times will proffer them its aid.

\section{THE ERUPTION OF MOUNT VESUVTUS}

$\mathrm{THE}$ great eruption of Mount Vesuvius, with the telegraphic accounts of which the readers of the daily papers have been familiar for the past week, is undoubtedly one of the most considerable of modern times. Whether the worst is yet over seems still uncertain while we are writing; but even if this be the case, the mass of molten lava ejected, and the amount of damage done, will appear to bear comparison with those of almost any recent eruption. One account speaks of it as the grandest eruption since $163 \mathrm{I}$.

The telegraphic accounts at present received are necessarily vague, and to a certain extent conflicting, and of course it is at present impossible to do more than chronicle. Scientific results must follow afterwards.

The correspondent of the Daily News says, under date of Sunday afternoon :- "I have just returned from risiting the spot where the victims of the eruption perished. Streams of lava, thirty metres wide and nearly ten metres in height, were still fiery and smoking. The detonations continue as before. Part of San Sebastiano is entirely destroyed, with everything near. King Victor Emmanuel and Signor Lanza were on the spot distributing money to the sufferers. All the people fled at the time, but some were beginning to return with their goods. The shower of cinders had ceased, the sky was blue, and Mount Vesuvius, with a colossal column of smoke above it, had a grandly imposing appearance."

San Sebastiano is a village on the north-western slope of Vesuvius, almost exactly in the direction of Naples. None of the earlier eruptions extended in this direction, but a stream of lava flowed almost close to the village in one of the early eruptions of this century. The lava is here spoken of as being sixteen feet deep in places, and in other despatches San Sebastiano and the neighbouring village of Masso di Somma are spoken of as having been nearly destroyed. This stream of lava is described as having several times changed its direction, and it is probably a branch of the same which has threatened Portici and Persina (no doubt Resina, almost close to Herculaneum) near the sea-coast, and caused the abandonment of these villages.

It must be a different stream which has partially or entirely destroyed Torre del Greco, one of the beautiful villages which lie on the shores of the Bay of Naples, in a south-westerly direction from the centre of the mountain. This village, or its immediate neighbourhood, has been overwhelmed several times within the last two centuries. The statement that "the lava now reaches from Torre del Greco to within five kilometres of the eastern coast, and threatens several other communes, the inhabitants of which have, in consequence, fled from their homes," is quite unintelligible.

The effect of the eruption at Naples up to Monday night is described as follows :- " Cinders fell all last night, and they still continue to fall at this moment as I send off the present despatch. A thin rain is also falling. Near Cercola the shower of scoriz has compelled the soldiers to build huts in which they may obtain shelter. The church of San Giordano at Cercola has been destroyed. A number of people have been surrounded by the lava close to San Sebastiano. At Ottoiano a heavy shower of enormous blocks of lava has commenced. The railway is crowded with foreigners and Neapolitans hurrying away. from Naples. A fresh eraption is feared, as loud explosions were heard last night even in this city."

The fall of cinders, even at Naples, is spoken of as so heavy that the sky seemed hidden by them, and they fell 